\title{
Molecular Detection of Phytophthora ramorum by Real-Time Polymerase Chain Reaction Using TaqMan, SYBR Green, and Molecular Beacons
}

\author{
G. J. Bilodeau, C. A. Lévesque, A. W. A. M. de Cock, C. Duchaine, S. Brière, P. Uribe, F. N. Martin, and R. C. Hamelin
}

First and eighth authors: Natural Resources Canada, Canadian Forest Service, Laurentian Forestry Centre, P.O. Box 3800 , 1055 du P.E.P.S., Sainte-Foy, Quebec, G1V 4C7, Canada; second author: Agriculture and Agri-Food Canada, National Program on Environmental HealthBiodiversity, 960 Carling Avenue, Ottawa, Ontario, K1A 0C6, Canada; third author: Centraalbureau voor Schimmelcultures, P.O. Box 85167, NL-3508 AD Utrecht, The Netherlands; fourth author: Département de biochimie et de Microbiologie, Université Laval, Pavillon Alexandre-Vachon, Quebec, Canada; Centre de Recherche de l'Hôpital Laval, 2725 chemin Sainte-Foy, Sainte-Foy, Quebec, G1V 4G5, Canada; fifth author: Pest DNA Diagnostics Laboratory, Centre for Plant Quarantine Pests, CFIA, Ottawa, Ontario, K2H 8P9, Canada; and sixth and seventh authors: U.S. Department of Agriculture-Agricultural Research Service (USDA-ARS), 1636 East Alisal St., Salinas, CA 93905.

Accepted for publication 22 November 2006.

\section{ABSTRACT}

Bilodeau, G. J., Lévesque, C. A., de Cock, A. W. A. M., Duchaine, C., Brière, S., Uribe, P., Martin, F. N., and Hamelin, R. C. 2007. Molecular detection of Phytophthora ramorum by real-time polymerase chain reaction using TaqMan, SYBR Green, and molecular beacons. Phytopathology 97:632-642.

Sudden oak death, caused by Phytophthora ramorum, is a severe disease that affects many species of trees and shrubs. This pathogen is spreading rapidly and quarantine measures are currently in place to prevent dissemination to areas that were previously free of the pathogen. Molecular assays that rapidly detect and identify $P$. ramorum frequently fail to reliably distinguish between $P$. ramorum and closely related species. To overcome this problem and to provide additional assays to increase confidence, internal transcribed spacer (ITS), $\beta$-tubulin, and elicitin gene regions were sequenced and searched for polymorphisms in a collection of Phytophthora spp. Three different reporter technologies were compared: molecular beacons, TaqMan, and SYBR Green. The assays differentiated $P$. ramorum from the 65 species of Phytophthora tested. The assays developed were also used with DNA extracts from 48 infected and uninfected plant samples. All environmental samples from which $P$. ramorum was isolated by PARP-V8 were detected using all three real-time PCR assays. However, $24 \%$ of the samples yielded positive real-time PCR assays but no $P$. ramorum cultures, but sequence analysis of the coxI and II spacer region confirmed the presence of the pathogen in most samples. The assays based on detection of the ITS and elicitin regions using TaqMan tended to have lower cycle threshold values than those using $\beta$-tubulin and seemed to be more sensitive.
Since 1995, extensive oak mortality, referred to as sudden oak death (SOD), has been reported in California. In 2001, a new pathogen called Phytophthora ramorum Werres, de Cock \& Man in't Veld, was described (60) and identified as the causal agent of SOD $(12,14,20,37,45,51)$. This pathogen has since spread to several counties in California (14 in 2004) and was discovered in Oregon in 2001 (22,33), but is now increasing its range. It was found again in 2003 in nurseries in Oregon, Washington, and British Columbia (25), and was subsequently eradicated from infested sites. In 2004, the pathogen was discovered in nurseries in several U.S. states and one Canadian province after a nursery in California shipped infected material across the continent. $P$. ramorum is also present in Europe where it has been reported in 14 countries, mostly in nurseries, but also in public parks, where it causes leaf blight and shoot dieback mainly in Rhododendron sp. and Viburnum sp. (16,32,36,44,46,58). Recently, it was found on southern red oak, Quercus falcata, in England where the bleeding canker symptoms typical of SOD were observed. $Q$. rubra is susceptible to $P$. ramorum in artificial inocu-

Corresponding author: R. C. Hamelin; E-mail address: rhamelin@cfl.forestry.ca

doi:10.1094/PHYTO-97-5-0632

This article is in the public domain and not copyrightable. It may be freely reprinted with customary crediting of the source. The American Phytopathological Society, 2007. lations and two trees have been found naturally infected in the Netherlands $(9,10,17)$.

$P$. ramorum infects a broad range of hosts and causes different symptoms, including cankers, leaf spots, blights, and diebacks (19). Inspection and proper diagnosis of nursery material can therefore be challenging especially on hosts for which the etiology has not been described. Experience in Europe and North America indicates that $P$. ramorum spreads readily on infected nursery material by zoospore release and that it may also be spread via chlamydospores in soil debris and rain splash (13).

In order to prevent the movement of material from infested to disease-free locations, state and federal quarantine measures were put into place in the United States and in Canada. Despite these measures, the disease spread to new locations along the coast of the Pacific Northwest in 2003 and 2004. Intensive surveys have been conducted in several countries, including Canada, where this pathogen could represent a risk, to determine whether it is present and to assess the extent of its distribution. Depending on jurisdiction and circumstances such as time of year, survey samples are tested by direct isolation on selective medium, or by some combination of isolation, enzyme-linked immunosorbent assay (ELISA), and polymerase chain reaction (PCR). One of the difficulties encountered with identifications based solely on morphology is that it requires mycological expertise and it does not always allow the distinction of variants within species. This is important in the case of $P$. ramorum since close relatives of $P$. ramorum exist in 
North America and isolates of $P$. ramorum from North America and Europe are genetically distinct $(8,29,30,35)$. Furthermore, seasonal variation in the ability to recover $P$. ramorum from infected fieldcollected tissue has been reported (27). Molecular diagnostic tools can allow rapid and sensitive pathogen detection and provide an increased confidence level in the identification, even when the pathogen cannot be isolated. Molecular assays have the advantage that they can be used on most types of material, from pure to mixed cultures of the pathogen or symptomatic to asymptomatic host tissue samples. However, identification of $P$. ramorum based solely on molecular methods can yield false positive results $(18,47,48,53)$ or questionable results that cannot be confirmed by isolation or other methods. Thus, identification of $P$. ramorum for regulatory purposes is most reliable when using a combination of molecular methods and other methods.

Recent phylogenetic analyses using internal transcribed spacer (ITS) (11) sequences of the rRNA cistron revealed a close relationship between $P$. ramorum and $P$. lateralis Tucker \& Milbrath, with a total of 12 single nucleotide polymorphisms between them $(18,51)$. In addition, other phylogenetic analyses of Phytophthora species conducted with mitochondrial and nuclear DNA sequences have revealed a close relationship with $P$. hibernalis $(34,38)$. Given the close phylogenetic relationships among these species, one PCR assay, developed from the ITS region, may not always reliably discriminate $P$. ramorum from $P$. lateralis or $P$. hibernalis $(18,47)$. This could be important since $P$. lateralis, the causal agent of Port Orford cedar root rot, is commonly found on the west coast of North America $(18,19,62)$. Other real-time PCR protocols were developed to detect $P$. ramorum and were using single gene detection $(26,27,53,54)$.

The objectives and approach of this investigation were the following: (i) to sequence two nuclear genes $(\beta$-tubulin and elicitin "ramorumin") of $P$. ramorum and related species and use existing ITS sequences to identify polymorphisms specific to $P$. ramorum; (ii) to design and test reverse transcription (RT)-PCR assays to specifically detect $P$. ramorum, based on the polymorphisms identified using three reporter technologies (SYBR Green, TaqMan probes, and molecular beacons targeting the three gene regions); and (iii) to validate the real-time PCR assays using DNA from pure cultures of a comprehensive collection of Phytophthora species and from infected plant samples.

\section{MATERIALS AND METHODS}

Isolates. All isolates of Phytophthora used in this study are listed in Table 1 . The $P$. ramorum collection comprised 38 isolates

TABLE 1. Isolates of Phytophthora species from different culture collections used in this study

\begin{tabular}{|c|c|c|c|c|c|}
\hline Phytophthora species & Collection number ${ }^{\mathrm{a}}$ & Phytophthora species & Collection number & $\begin{array}{l}\text { Phytophthora } \\
\text { species }\end{array}$ & Collection number \\
\hline $\operatorname{arecae}^{\mathrm{b}}$ & CBS 305.62 & katsurae $^{\mathrm{b}}$ & CBS 587.85 & & \\
\hline boehmeriae $^{\mathrm{b}}$ & CBS 291.29 & lateralis $^{\mathrm{bc}}$ & ATCC201856 & ramorum & CBS 110544 \\
\hline botryosa $^{\mathrm{b}}$ & CBS 581.69 & lateralis & CBS 168.42 & ramorum & CBS 109278 \\
\hline brassicae $^{\mathrm{b}}$ & CBS 178.87 & meadii ${ }^{\mathrm{b}}$ & CBS 219.88 & ramorum $^{\mathrm{c}}$ & CBS 101552 \\
\hline brassicae $^{\mathrm{b}}$ & CBS 686.95 & megakarya $^{\mathrm{b}}$ & CBS 238.83 & ramorum & CBS 101549 \\
\hline cactorum $^{\mathrm{b}}$ & CBS 108.09 & megasperma ${ }^{\mathrm{b}}$ v. megasperma & CBS 402.72 & ramorum & CBS 101331 \\
\hline cactorum $^{\mathrm{b}}$ & CBS 108.09 & melonis ${ }^{\mathrm{b}}$ & CBS 582.69 & ramorum & CBS 110535 \\
\hline cactorum $^{\mathrm{c}}$ & DAOM BR 675 & mexicana $^{\mathrm{b}}$ & CBS 554.88 & ramorum & CBS 110547 \\
\hline cambivora $^{\mathrm{b}}$ & CBS 248.60 & mirabilis $^{\mathrm{b}}$ & CBS 678.85 & ramorum & CBS 1110536 \\
\hline capsici $^{\mathrm{b}}$ & CBS 128.23 & multivesiculata $^{\mathrm{b}}$ & CBS 545.96 & ramorum & CBS 110542 \\
\hline cinnamomi $i^{\mathrm{b}}$ & CBS 144.22 & nicotianae $^{\mathrm{b}}$ & CBS 305.29 & ramorum & CBS 110534 \\
\hline cinnamomi $^{\mathrm{bc}}$ & DAOM BR 680 & nicotianae $^{\mathrm{b}}$ (type of terrestris) & CBS 109.17 & ramorum & CBS 110900 \\
\hline cinnamomi $^{\mathrm{b}} \mathrm{v}$. parvispora & CBS 413.96 & operculata $^{\mathrm{b}}$ & CBS 241.83 & ramorum & CBS 110901 \\
\hline cinnamomi $^{\text {b }}$ var. parvispora & CBS 411.96 & palmivora ${ }^{\mathrm{b}}$ & CBS 236.30 & ramorum & adc 01.01 \\
\hline citricola $^{\mathrm{b}}$ & CBS 221.88 & phaseoli $^{\mathrm{b}}$ & CBS 556.88 & ramorum & adc 01.06 \\
\hline citricola $^{\mathrm{c}}$ & DAOM BR 681 & primulae $^{\mathrm{b}}$ & CBS 275.74 & ramorum & DAOM 229466 \\
\hline citricola $^{\mathrm{b}}$ (type of $P$. pini) & CBS 181.25 & pseudosyringae & EH P96 & ramorum & DAOM 230729 \\
\hline citrophthora ${ }^{\mathrm{b}}$ & CBS 950.87 & pseudotsugae & CBS 444.84 & ramorum $^{\mathrm{c}}$ & DAOM 230728 \\
\hline clandestina $^{\mathrm{b}}$ & CBS 347.86 & psychrophila ${ }^{\mathrm{b}}$ & CBS 803.95 & ramorum & DAOM 230727 \\
\hline colocasiae $^{\mathrm{b}}$ & CBS 955.87 & quercina $^{\mathrm{b}}$ & CBS 784.95 & richardiae $^{\mathrm{b}}$ & CBS 240.30 \\
\hline cryptogea $^{\mathrm{b}}$ & CBS 113.19 & ramorum & CBS 101327 & sinensis $^{\mathrm{b}}$ & CBS 557.88 \\
\hline cryptogea $^{\mathrm{a}}$ f. sp. begoniae & CBS 468.81 & ramorum & CBS 101326 & sojae $^{\mathrm{b}}$ & CBS 418.91 \\
\hline drechsleri $^{\mathrm{b}}$ & CBS 291.35 & ramorum & CBS 110538 & sojae $^{\mathrm{b}}$ & CBS 382.61 \\
\hline erythroseptica ${ }^{\mathrm{b}}$ & CBS 129.23 & ramorum & CBS 110601 & sp. b ('aquatica') & CBS 363.79 \\
\hline 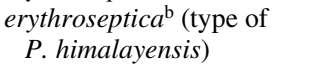 & CBS 357.59 & ramorum & CBS 110543 & $\mathrm{sp}^{\mathrm{b}}$ ('marine') & CBS 215.85 \\
\hline erythroseptica ${ }^{\mathrm{b}}$ var. pisi & adc 99.69 & ramorum & CBS 110537 & syringae $^{\mathrm{b}}$ & CBS 132.23 \\
\hline europea ${ }^{\mathrm{b}}$ & CBS 109049 & ramorum & CBS 110541 & syringae $^{\mathrm{b}}$ & CBS 367.79 \\
\hline fragariae $^{\mathrm{b}} \mathrm{v}$. fragariae & CBS 209.46 & ramorum & CBS 110539 & tartarea $^{\mathrm{b}}$ & CBS 208.95 \\
\hline fragariae $^{\mathrm{b}}$ var. rubi & CBS 967.95 & ramorum $^{\mathrm{b}}$ & CBS 109279 & tentaculata $^{\mathrm{b}}$ & CBS 552.96 \\
\hline gonapoyides $^{\mathrm{b}}$ & CBS 554.67 & ramorum & CBS 101554 & tropicalis $^{\mathrm{b}}$ & CBS 434.91 \\
\hline heveae $\mathrm{b}^{\mathrm{b}}$ & CBS 296.29 & ramorum & CBS 110545 & uliginosa $^{\mathrm{b}}$ & CBS 109054 \\
\hline hibernalis $^{\mathrm{b}}$ & CBS 522.77 & ramorum & CBS 110548 & vignae $^{\mathrm{b}}$ & CBS 241.73 \\
\hline humicola $^{\mathrm{b}}$ & CBS 200.81 & ramorum & CBS 101553 & & \\
\hline idaei $^{\mathrm{b}}$ & CBS 971.95 & ramorum & CBS 101329 & & \\
\hline ilicis $^{\mathrm{b}}$ & CBS 255.93 & ramorum & CBS 101551 & & \\
\hline infestans $^{\mathrm{bc}}$ & CBS 366.51 & ramorum $^{\mathrm{b}}$ & CBS 101332 & & \\
\hline insolita $^{\mathrm{b}}$ & CBS 691.79 & ramorum & CBS 101330 & & \\
\hline iranica $^{\mathrm{b}}$ & CBS 374.72 & ramorum & CBS 110546 & & \\
\hline \multirow[t]{2}{*}{ kandelii $^{\mathrm{b}}$} & CBS 111.91 & ramorum & CBS 101548 & & \\
\hline & & ramorum & CBS 101550 & & \\
\hline
\end{tabular}

${ }^{a}$ CBS, Centraalbureau voor Schimmelcultures; DAOM, Canadian Agriculture and Agri-Food Canada, Ottawa; adc, A. W. A. M. de Cock; ATCC, American Type Culture Collection; and EH, E. Hansen collection.

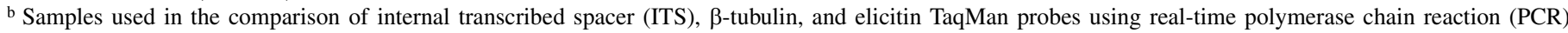
tested with 65 species of Phytophthora.

c Sample used in Figure 1: real-time PCR of Phytophthora samples with TaqMan, molecular beacons, and SYBR Green ( $\beta$-tubulin gene). 
from European and North American origin isolated from different hosts. The Phytophthora collection comprised isolates of 65 different species and varieties, representing most of the recognized Phytophthora species currently available in pure culture. Mycelium was cultivated and DNA was extracted following the procedures described in De Cock et al. (15) or Möller et al. (43).

DNA sequencing. The primers listed in Table 2 were used to amplify three gene regions of the nuclear DNA of P. ramorum and related Phytophthora species by PCR (Table 1). Primers for the $\beta$ tubulin and the elicitin genes were designed based on sequences of these genes obtained from $P$. parasitica (GenBank accession no. S67432) for elicitin, and P. cinnamomi (GenBank accession no. U22050) for $\beta$-tubulin. ITS primers used were from Bakkeren et al. (4) and Mazzola et al. (41), and the sequence AY038050 from GenBank for P. ramorum was used for alignment. These nuclear regions were selected because of the high level of sequence divergence among species that were observed in preliminary results and large number of sequence entries available in public databases.

Genomic DNA from $P$. ramorum (CBS 101553, DAOM 230728) and other species was amplified using these genusspecific primers. Most reactions yielded a single band. However, multiple bands were amplified for the elicitin gene of $P$. lateralis ATCC 201856, $P$. cactorum BR675, $P$. citricola BR 681, $P$. cinnamomi BR 680, and $P$. infestans CBS 366.51. A band of approximately $280 \mathrm{bp}$ was cut and extracted from agarose gels with the QIAEX II agarose gel extraction kit (Qiagen, Valencia, CA). PCR products were then re-amplified.

PCR products were purified with the QIAquick PCR purification kit (Qiagen) using the microfuge method, quantified, and sequenced using the same primers as for PCR. Sequencing reactions were performed with a Big Dye Terminator Sequencing kit on an ABI 310 automated sequencer (PE Applied Biosystems, Foster City, CA). Both strands were sequenced with the primers listed in Table 2. Sequences were aligned using Sequencher version 4.0.5 (Gene Codes Corporation, Ann Arbor, MI) and MegAlign version 5.08 (DNASTAR Inc., Madison, WI) using
Clustal W. The sequences were deposited in GenBank and the accession numbers are listed in Table 3.

Design of primers. The alignments of sequences listed in Table 3 were used to design PCR primers specific to $P$. ramorum (Table 2) using the software Primer Premier 5.00 (Premier Biosoft International, Palo Alto, CA). The selection criteria were the following: Tm (melting temperature) 55 to $65^{\circ} \mathrm{C}$, primer length 18 to $22 \mathrm{bp}$, and absence of secondary structure whenever possible. Specific primers were designed so that the nucleotides unique to the target were at the $3^{\prime}$ end position of the primer. In primers Phy_ram_482U_LNA F and Prameli259L R (Table 2), positioning the discriminating site at the $3^{\prime}$ end resulted in secondary structures and the primers were moved toward the $5^{\prime}$ end. The primer pairs were designed such that PCR products were shorter than $200 \mathrm{bp}$, an important parameter for RT-PCR. In cases where only single nucleotide differences were present and unmodified primers did not allow specific amplifications, primers were synthesized with a lock nucleic acid (LNA) (7) (Proligo LLC, Boulder, CO) to increase specificity. The ITS primers were different from other published primers $(18,26,27)$ and instead targeted positions 622 to 755 with mismatches at the $3^{\prime}$ site and the LNA modification.

Design of molecular beacon and TaqMan probes. Molecular beacons were designed using Mfold version 3.1 (DNA mfold server: 1996 to 2003, Michael Zuker, Rensselaer Polytechnic Institute) and Beacon designer 3 software (Premier Biosoft International, Palo Alto, CA) to calculate the Tm and the structure of the molecule. The molecular beacon was labeled with fluorescein $\left(6-\mathrm{FAM}^{\mathrm{tm}}\right)$ at the $5^{\prime}$ end and with the quencher Dabcyl at the $3^{\prime}$ end $(6,55,56)$. TaqMan probes $(28)$ were designed with Primer Premier 5.00. We used the following parameters for the design: $\mathrm{Tm} 10^{\circ} \mathrm{C}$ higher than the primers, 15 to $30 \mathrm{bp}$ in length and the total number of G's or C's in the last five nucleotides at the $3^{\prime}$ end of the primer not exceeding two. The mismatching nucleotide was positioned as close as possible to the middle of the probe rather than at the ends while avoiding positions with secondary structures. The TaqMan probes were labeled with fluorescein (6-

TABLE 2. Primers and probes used for polymerase chain reaction assays targeting Phytophthora spp. and P. ramorum

\begin{tabular}{|c|c|c|c|}
\hline Name $^{\mathrm{a}}$ & Primer sequence & Region & Notes \\
\hline \multicolumn{4}{|c|}{ Universal to Phytophthora species } \\
\hline Oom-Btub-up415 F & 5'-CGCATCAACGTGTACTACAA-3' & $\beta$-tubulin & $\approx 539 \mathrm{bp}$ \\
\hline Oom(Ph)-Btub-lo954 R & 5'-GCACACCAGGTGGTTC-3' & & \\
\hline Oom(Ph)-Btub-up901 F & 5'-TACGACATTTGCTTCCG-3' & $\beta$-tubulin & $\approx 500 \mathrm{bp}$ \\
\hline Oom-Btub-lo1401 R & 5'-CGCTTGAACATCTCCTGG-3' & & \\
\hline UN-UP18S42 F & 5'-CGTAACAAGGTTTCCGTAGGTGAAC-3' & ITS & $\approx 350 \mathrm{bp}$ \\
\hline OOM-LO5.8S47 R & 5'-ATTACGTATCGCAGTTCGCAG-3' & & \\
\hline OOM-UP5.8S-55 F & 5'-TGCGATACGTAATGCGAATT-3' & ITS & $\approx 650 \mathrm{bp}$ \\
\hline UN-LO28S22 $\mathrm{R}^{\mathrm{b}}$ & 5'-GTTTCTTTTCCTCCGCTTATTGATATG-3' & & \\
\hline Phy_elicitor1 F & 5'-GCCCTCGTCGGCTCCAC-3' & Elicitin & $\approx 300 \mathrm{bp}$ \\
\hline Phy_elicitor2 R & 5'-GTGAACACGTTGAGTACCAGGC-3' & & \\
\hline \multicolumn{4}{|l|}{ Specific to $P$. ramorum $^{\mathrm{d}}$} \\
\hline Phy_ram_482U_LNA F & 5'-GGCGCTGTACGACATTTG-3' & & LNA modified $171 \mathrm{bp}$ \\
\hline Phy_ram_653L_LNA R & 5'-ACGCGGGAACGGAATCA & $\beta$-tubulin & \\
\hline ITSPrim622U F- & 5'-AATGACTGGTGAACCGTAGCTG-3' & & \\
\hline ITSPrimer755L R & 5'-CGAAGCCGCCAACACAAG-3' & ITS & LNA modified $133 \mathrm{bp}$ \\
\hline Prameli 102U F & 5'-TTCAACCAGTGCGCGACE- & Elicitin & \\
\hline Prameli259L R & 5'-GGCACAGTCA GCTCGCAGTC-3' & Elicitin & \\
\hline \multicolumn{4}{|l|}{ Molecular beacon } \\
\hline Beacon4. Beta tub F & 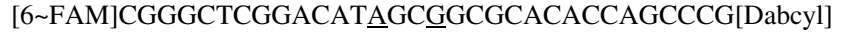 & $\beta$-tubulin & $157 \mathrm{bp}$ \\
\hline \multicolumn{4}{|l|}{ TaqMan probes } \\
\hline TaqMan581L R & [6 FAM]CGTGGTGATGCCGGACAT $\underline{A G C G}[\mathrm{BHQ} 1 \sim \mathrm{Q}]^{\mathrm{e}}$ & $\beta$-tubulin & \\
\hline TaqManITSGB651L R & 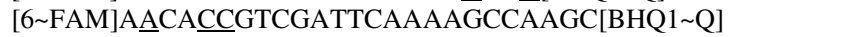 & ITS & \\
\hline Taq195eli R & [6 FAM]CㅡGTGGACGCGEACATGAGCGAGTAC[BHQ1 Q] & Elicitin & \\
\hline
\end{tabular}

${ }^{\text {a }} \mathrm{F}$, forward primers; $\mathrm{R}$, reverse primers.

b Bakkeren et al. 2000 (4).

c Mazzola et al. 2002 (41).

d Polymorphisms with the most closely related species are underlined. Bases with locked nucleic acid modification are in bold box.

e BHQ1 Q: Black hole quencher-Quencher. 
$\mathrm{FAM}^{\mathrm{tm}}$ ) at the $5^{\prime}$ end and with the quencher Black Hole Quencher $^{\mathrm{tm}}-1$ (BHQ $\left.{ }^{\mathrm{tm}}-1\right)$ at the $3^{\prime}$ end (Integrated DNA Technologies Inc., Coralville, IA).

PCR amplification. Real-time PCR was performed with a DNA Engine Opticon 2 Real-Time PCR Detection System (BioRad Laboratories, Hercules, CA). Fluorescent molecules (SYBR Green, dual-labeled probe [TaqMan or molecular beacons]) were included in the PCR master mix (QuantiTect, Qiagen). All reactions were performed in $25 \mu \mathrm{l}$ volumes. The DNA concentration used in the reaction was determined with a Nanodrop spectrophotometer ND-1000 (Nanodrop Technologies, Wilmington, DE) and ranged from 0.05 to $60 \mathrm{ng} / \mu \mathrm{l}$ for $P$. ramorum and from 5 and $110 \mathrm{ng} / \mu \mathrm{l}$ for other Phytophthora sp. Molecular beacon, TaqMan and SYBR Green real-time PCR assays were used in a preliminary experiment with the three gene regions using a subset of isolates. The real-time PCR on P. ramorum tested on the three gene regions were made in triplicates, and the mean and standard error were calculated for each. Subsequently, TaqMan assays were used for further studies using 48 plant tissue samples from seven hosts. $P$. ramorum CBS 101553 was used as positive control, and $P$. lateralis CBS 168.42 and no template DNA were used as negative controls. The analysis software Opticon Monitor version 2.01.10 (Bio-Rad Laboratories) was used to analyze the data (cycle range set at 1 to 21). Data were exported as cycle threshold $(\mathrm{Ct})$ values and analyzed for comparisons among samples in Excel spreadsheets. Statistical analyses were performed with Excel (Microsoft Excel version 9.0.3821 SR-1, Redmond, WA). The specific reaction conditions for each of the three detection technologies tested were set up as follows.

SYBR Green. The PCR assay contained $0.4 \mu \mathrm{M}$ of each LNA primer or regular primer (Table 2), 1× QuantiTect SYBR Green PCR Kit (Qiagen), and template DNA. PCR cycling conditions were set at $95^{\circ} \mathrm{C}$ for $15 \mathrm{~min}, 40$ cycles at $94^{\circ} \mathrm{C}$ for $15 \mathrm{~s}, 60^{\circ} \mathrm{C}$ for $30 \mathrm{~s}$, and $72^{\circ} \mathrm{C}$ for $30 \mathrm{~s}$. Fluorescence was read during the extension at $72^{\circ} \mathrm{C}$.

TaqMan probe. The PCR assay contained $0.4 \mu \mathrm{M}$ of each LNA primer or regular primer depending on the region used, $0.2 \mu \mathrm{M}$ TaqMan (dual-labeled probe) (Table 2), 1× QuantiTect Probe PCR Master Mix (Qiagen), and template DNA. PCR cycling conditions were set at $95^{\circ} \mathrm{C}$ for $15 \mathrm{~min}, 36$ cycles at $94^{\circ} \mathrm{C}$ for $15 \mathrm{~s}$, and $65^{\circ} \mathrm{C}$ for $60 \mathrm{~s}\left(68^{\circ} \mathrm{C}\right.$ for $60 \mathrm{~s}$ for elicitin). Cycle number was extended to 40 to 45 for $\beta$-tubulin and ITS on environmental samples to increase sensitivity. Fluorescence was read during the extension at 65 to $68^{\circ} \mathrm{C}$.

Molecular beacon. The PCR assay contained $0.4 \mu \mathrm{M}$ of each LNA primer for $\beta$-tubulin (Table 2), $0.2 \mu \mathrm{M}$ molecular beacon probe (Table 2), 1× QuantiTect Probe PCR Master Mix, and template DNA. PCR cycling conditions were set at $95^{\circ} \mathrm{C}$ for $15 \mathrm{~min}$, 36 cycles at $94^{\circ} \mathrm{C}$ for $15 \mathrm{~s}, 65^{\circ} \mathrm{C}$ for $30 \mathrm{~s}$, and $72^{\circ} \mathrm{C}$ for $30 \mathrm{~s}$. Fluorescence was read after the annealing at $65^{\circ} \mathrm{C}$. This allows the molecular beacon to open and anneal with the target sequence.

Standard curves. Serial dilutions of $P$. ramorum DNA were used to calculate amplification efficiency with TaqMan assays. DNA serial dilutions consisted of $P$. ramorum strain CBS 101327 with an estimated initial concentration of $10 \mathrm{ng} / \mu \mathrm{l}$ diluted in a series of 1:10 from $1 \mathrm{ng} / \mu \mathrm{l}$ to $1 \mathrm{fg} / \mu \mathrm{l}$. Three dilution series were done with Tris buffer, $10 \mathrm{mM}, \mathrm{pH} 8.0$, Rhododendron sp. DNA (38.8 ng/ $\mu \mathrm{l})$ and $P$. monticola DNA (3.5 $\mathrm{ng} / \mu \mathrm{l})$. Standard curves were replicated for each marker twice for each dilution. The results were analyzed by plotting the Log of template concentration against $\mathrm{Ct}$ values. PCR efficiency was calculated with the formula $E=\left(10^{(-1 / \text { slope })}-1\right) \times 100$, where $E$ is the amplification efficiency and the slope is derived from the plot of Log of template concentration versus Ct. A slope of 3.32 translates into $100 \%$ efficiency of amplification.

DNA extraction and pathogen isolation from infected plant material. To test sensitivity and specificity of the assays on infected plant material, environmental samples were obtained from different hosts either healthy or naturally infected by the pathogen. Samples were collected on 14 June 2005, at Pfeiffer Big Sur State Park, Monterey County, CA, and processed at the U.S. Department of Agriculture-Agricultural Research Service (USDAARS) station in Salinas, CA. Protocols for sample collection and handling followed California Oak Mortality Task Force (Pest alert 6, Diagnosis and Monitoring of Sudden Oak Death, March 2002) recommendations. Briefly, symptoms resembling SOD were sought in the field. Leaf blights and diseased twigs of plants belonging to host species such as bay laurel (Umbellularia californica), madrone (Arbutus menziesii), coffee berry (Frangula californica), Christmas berry (Heteromeles arbutifolia), and tan oak (Lithocarpus densiflorus) were individually collected, annotated, and stored in cold for transportation and processing. For comparison purposes samples of healthy hosts such as camellia (Camellia spp.) and live oak ( $Q$. agrifolia) were collected at the USDA/ARS station in Salinas, CA. Samples were superficially cleaned from excess soil and debris with sterile water and blot dried. For species in which the pathogen typically causes cankers such as tan oaks and live oaks, often necrosis of twigs and wilting of small branches signal ongoing infections. Therefore, instead of sampling the bark, wilting twigs were collected. This type of sample has been shown to correlate with $P$. ramorum infection and to subsequently produce symptoms such as shoot tip dieback, leaf flagging, or the formation of a Shepard's crook (14). Once in the laboratory, tan oak leaves including the petioles were used as starting material to isolate the pathogen. Particular care was given to use adjacent tissues of the infected sample to perform the in vitro culture and DNA isolation of the pathogen.

TABLE 3. Isolates of Phytophthora species sequenced in this study and GenBank accession numbers for $\beta$-tubulin and elicitin genes

\begin{tabular}{|c|c|c|c|}
\hline \multirow[b]{2}{*}{ Species } & \multirow{2}{*}{$\begin{array}{l}\text { Collection } \\
\text { number }^{\mathrm{b}}\end{array}$} & \multicolumn{2}{|c|}{ GenBank accession number ${ }^{\mathrm{a}}$} \\
\hline & & $\beta$-Tubulin & Elicitin \\
\hline P. ramorum & DAOM 229466 & AY766201 & - \\
\hline P. ramorum & DAOM 230729 & AY766202 & - \\
\hline P. ramorum & DAOM 230728 & AY766203 & AY766222 \\
\hline P. ramorum & DAOM 230727 & AY766204 & - \\
\hline P. ramorum & CBS 109279 & AY766205 & - \\
\hline P. ramorum & CBS 109278 & AY766206 & - \\
\hline P. ramorum & CBS 101554 & AY766207 & - \\
\hline P. ramorum & CBS 101551 & AY766208 & - \\
\hline P. ramorum & CBS 101550 & AY766209 & - \\
\hline P. ramorum & CBS 101548 & AY766210 & - \\
\hline P. ramorum & CBS 101332 & AY766211 & - \\
\hline P. ramorum & CBS 101330 & AY766212 & - \\
\hline P. ramorum & CBS 101327 & AY766213 & - \\
\hline P. ramorum & CBS 101552 & AY766214 & - \\
\hline P. ramorum & CBS 101326 & AY766215 & - \\
\hline P. ramorum & adc 01.01 & AY766216 & - \\
\hline P. ramorum & adc 01.06 & AY766217 & - \\
\hline P. ramorum & CBS 101553 & AY766218 & AY766223 \\
\hline P. ramorum & CBS 110537 & - & AY766231 \\
\hline P. ramorum & CBS 110541 & - & AY766232 \\
\hline P. ramorum & CBS 110545 & - & AY766233 \\
\hline P. ramorum & CBS 110900 & - & AY766234 \\
\hline P. ramorum & CBS 110901 & - & AY766235 \\
\hline P. lateralis & CBS 168.42 & AY766219 & AY766225 \\
\hline P. cactorum & CBS 108.09 & AY766220 & - \\
\hline P. cinnamomi & CBS 144.22 & AY766221 & - \\
\hline P. lateralis & ATCC 201856 & - & AY766224 \\
\hline P. cactorum & DAOM BR 675 & - & AY766226 \\
\hline P. cinnamomi & DAOM BR 680 & - & AY766227 \\
\hline$P$. infestans & CBS 366.51 & _- & AY766228 \\
\hline P. citricola & DAOM BR 681 & - & AY766229 \\
\hline
\end{tabular}

a Alignments are available for those sequences as a popset on Genbank. - Indicates no sequence data.

${ }^{\mathrm{b}}$ CBS, Centraalbureau voor Schimmelcultures; DAOM, Canadian Agriculture and Agri-Food Canada, Ottawa; adc, A. W. A. M. de Cock; and ATCC, American Type Culture Collection. 
Host DNA was isolated using the USDA-APHIS protocol with the Qiagen DNeasy kit (1). For control purposes, most of the healthy samples of live oak and camellia were spiked with $P$. ramorum CBS 101553 and $P$. pseudosyringae EH P96 DNA. Aliquots of the DNA samples were coded and sent blind to our laboratory for testing. Pathogen isolation was done on PARP (pimaricin-ampicillin-rifampicin-PCNB agar) media (31).

In addition, environmental samples were tested with a coxI/II TaqMan in RT-PCR (54). To confirm that P. ramorum was present in PARP (-)/RT-PCR (+) amplicons, Phytophthora genus-specific primers were used to amplify the spacer regions between the coxI and II genes and this amplicon was sequenced as previously described (39).

\section{RESULTS}

Phytophthora sequence divergence. Approximately $2 \mathrm{~kb}$ for the two nuclear genes and ITS ribosomal DNA region was sequenced from several Phytophthora species (Table 3). Depending on the species, close to 866,260 , and 780 bp were sequenced for $\beta$-tubulin, elicitin, and the ITS, respectively. Divergence was the highest for $\beta$-tubulin and elicitin for comparisons between the two closely related species $P$. ramorum and $P$. lateralis. A total of $18 / 866$ bases for $\beta$-tubulin (2.2\% divergence) and $4 / 93$ bases for elicitin (4.5\% divergence) were polymorphic between these two species. In contrast, the ITS contained only 13 polymorphisms out of 783 bases (1.4\% divergence) between these two species. However, divergence among species was greater for comparisons with more distant Phytophthora species. For example, divergence between $P$. ramorum and $P$. cactorum was $6.0,11.4$, and $10.8 \%$ for $\beta$-tubulin, elicitin, and ITS, respectively. Similarly, divergence between $P$. ramorum and $P$. cinnamomi was $7.5,9.8$, and $12.2 \%$ for these three genes. A similar level of sequence divergence was observed in comparisons with $P$. citricola, $P$. infestans, and $P$. nicotianae. However, the low number of polymorphisms in $\beta$ tubulin was still sufficiently high among the distant species to design specific primers and probes for P. ramorum.

$\beta$-Tubulin PCR assays with TaqMan, molecular beacon, and SYBR Green. Using the $\beta$-tubulin primers, the three PCR reporter technologies were compared. PCR primers specific to $P$. ramorum were designed for $\beta$-tubulin to amplify an amplicon of $171 \mathrm{bp}$. The primers contained several nucleotides polymorphic among Phytophthora species used in this study (Tables 2 and 3). However, because of the low divergence between $P$. ramorum and $P$. lateralis, and the constraints with designing primers to amplify amplicons less than 200 bp for real-time PCR assays, both $\beta$ tubulin primers contained only one polymorphic nucleotide and were modified with LNA to increase specificity. Specificity of the $\beta$-tubulin assays was compared for TaqMan, molecular beacon, and SYBR Green in real-time PCR initially on P. ramorum, $P$. lateralis, $P$. cactorum, $P$. cinnamomi, $P$. citricola, and $P$. infestans (Fig. 1), representing closely related as well as more diverged species.

All real-time PCR assays targeting the $\beta$-tubulin gene yielded $\mathrm{Ct}$ values for the $P$. ramorum samples, but the $\mathrm{Ct}$ varied according to the reporter technology used. The TaqMan, SYBR Green, and molecular beacon assays yielded $\mathrm{Ct}$ values of 22.04, 22.77, and 25.08 , respectively. No amplifications were observed with the nontarget Phytophthora species tested. Since PCR efficiencies were comparable among the three assays (data not shown) and based on the fact that TaqMan probes are easier to design than molecular beacon, we designed TaqMan reporter probe assays for the comparison of PCR efficiencies in the three genes targeted (Table 2).

Comparison of ITS, $\beta$-tubulin, and elicitin TaqMan probes using real-time PCR. To compare the specificity and sensitivity

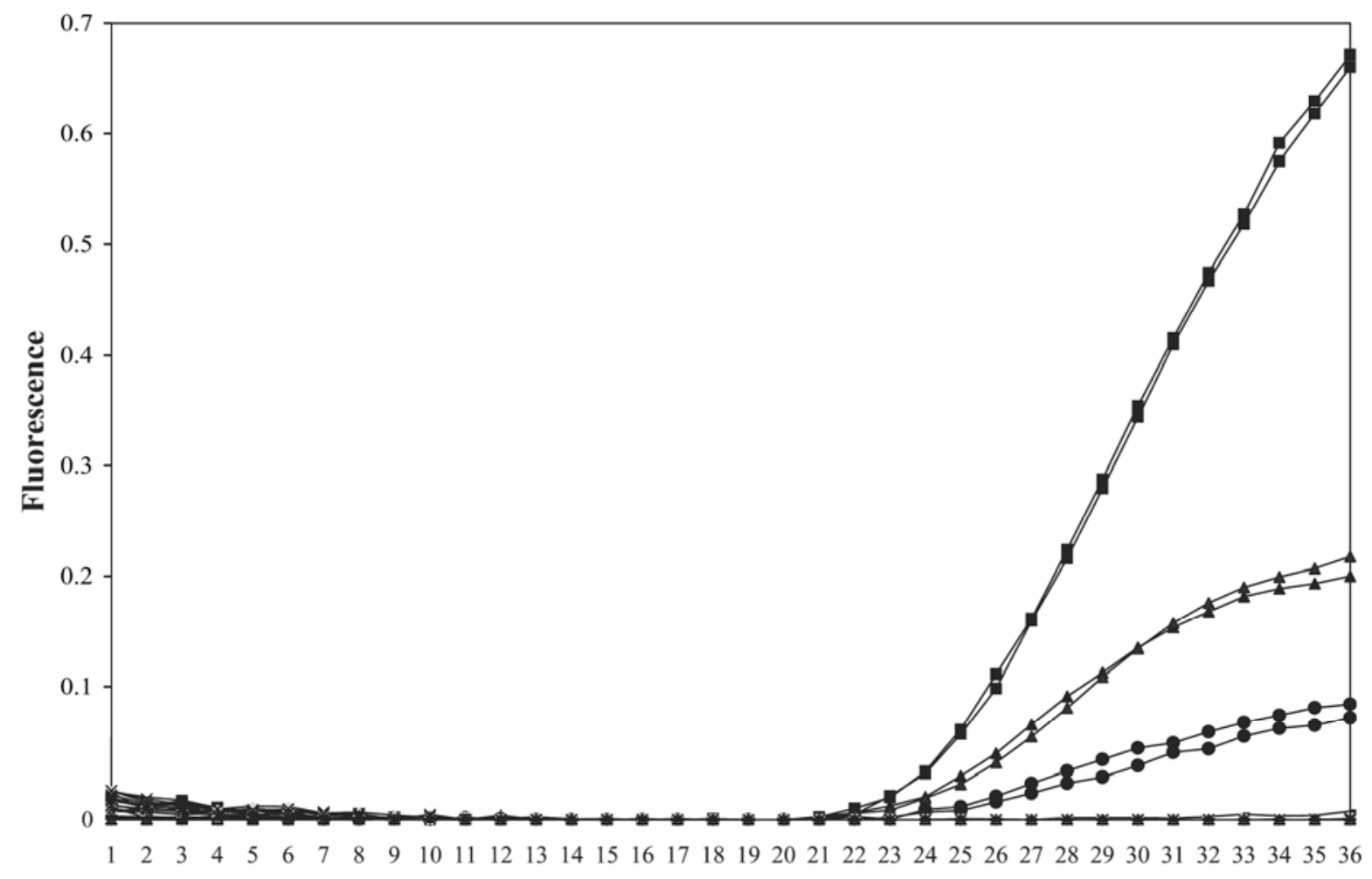

Cycles

Fig. 1. Real-time polymerase chain reaction of Phytophthora species assayed with TaqMan $(\bullet)$, molecular beacons $(\bullet)$, and SYBR Green $(\boldsymbol{\Delta})$, targeting the $\beta$ tubulin gene. The Phytophthora species used were: P. ramorum 230928, P. ramorum 230991; all other species used are P. lateralis ATCC 201856, P. cactorum BR675, P. cinnamomi BR680, P. citricola BR681, P. infestans M0014, and a negative control (water) and are represented by the $\times$. Threshold was set at 0.009 , with a cycle range of 1 to 15 . 
of probes in different gene regions, we focused on the TaqMan assay using DNA from 65 species of Phytophthora (Table 1) from pure cultures. Again, the $\mathrm{Ct}$ values for $P$. ramorum varied according to the gene region targeted. Ct values were 20.8 for the ITSTaqMan and 21.4 for the elicitin-TaqMan real-time PCR assays. The $\beta$-tubulin TaqMan assay yielded the highest $\mathrm{Ct}$ values $(\mathrm{Ct}=$ 24.4). None of the remaining Phytophthora spp. templates yielded $\mathrm{Ct}$ values with any of the TaqMan real-time PCR assays, indicating that the assays were highly specific, including species that frequently cross-react with $P$. ramorum such as $P$. pseudosyringae, $P$. nemorosa, and $P$. kernoviae (not shown).

Standard curves with serial dilutions of $P$. ramorum DNA were generated to calculate amplification efficiency. Amplification efficiencies were 100, 91, and 100\%, in TaqMan assays targeting ITS, elicitin, and $\beta$-tubulin diluted in Tris- $\mathrm{HCl}$ (Fig. 2). Addition of plant DNA from pine changed amplification efficiencies for these markers to 86,100 , and $91 \%$, respectively, while rhododendron DNA changed them to 78,100 , and $91 \%$ (data not shown). The limit of detection was 1, 10, and $100 \mathrm{fg}$ for the ITS, elicitin, and $\beta$-tubulin TaqMan assays, respectively (Fig. 2).

To determine whether the developed assays were applicable to a broad range of $P$. ramorum sources, 30 isolates of $P$. ramorum from Europe and North America (Table 4) were tested with the TaqMan probes for the three different gene regions. All reactions with $P$. ramorum isolates resulted in fluorescent curves that rose above the threshold value, regardless of the gene targeted by the real-time PCR assay (Table 4). Again, the $\mathrm{Ct}$ values varied according to the gene targeted, with $\mathrm{Ct}$ values for $P$. ramorum averaging 20.02 (standard error [SE] 2.97), 20.65 (SE 2.46), and 24.70 (SE 2.57) for the ITS, elicitin, and $\beta$-tubulin, respectively (Table 4). The relatively large SE reflects the variability in initial DNA concentration (ranging from 2 to $32 \mathrm{ng}$ ).

Detection of $\boldsymbol{P}$. ramorum in infected samples. To determine the reliability of the assays to amplify $P$. ramorum DNA from infected plant samples and from samples spiked with Phytophthora DNA, the three TaqMan real-time PCR assays were used to test 48 different plant extracts from seven hosts in a blind test (Table 5). All samples were plated on PARP-V8 medium and tested using coxI/II RT-PCR (54) at the USDA-ARS laboratory in Salinas, CA, and assayed in a blind test at the Laurentian Forestry Centre laboratory. All samples spiked with $P$. ramorum were detected accurately using all of the assays developed in this study, and were concordant with the coxI/II assays. All of the environmental samples gave concordant results for the four molecular assays, including $63 \%$ negatives and $13 \%$ positives (excluding spiked samples). All environmental samples that were naturally infected and yielded $P$. ramorum cultures on PARP-V8 as well as positive PCR results with the $\operatorname{coxI} / \mathrm{II}$ assay were positive with the ITS, $\beta$-tubulin, and elicitin assays. There was some level of discordance among the results for the molecular assays and the results of the culture isolation; the pathogen was not recovered from $24 \%$ of the samples that were PCR positive. The presence of $P$. ramorum in all but four of these samples was confirmed by sequence analysis of the spacer region between the coxI and II genes amplified using Phytophthora genus-specific primers (data not shown). The sample spiked with $P$. pseudosyringae was negative with all molecular assays. There were some cross reactions with $P$. lateralis at a high DNA concentration $(8 \mathrm{ng} / \mu \mathrm{l})$ with the elicitin TaqMan assay with a $\mathrm{Ct}$ value that was higher than the target. However, the results of the ITS assay were negative and the $\mathrm{Ct}$ for the $\beta$-tubulin assay was 41 , above what normally would be considered a positive sample.

$\mathrm{Ct}$ values in samples from infected material were higher than in the pure culture assays described in the previous sections. The $\mathrm{Ct}$ values ranged from 23 to 39 (TaqMan-ITS) to 28 to 40 (TaqMan$\beta$-tubulin) and 21 to 34 (TaqMan-elicitin) in environmental samples that were tested positive (Table 5).

\section{DISCUSSION}

Real-time PCR has been used in plant pathology for DNA quantification and diagnosis of several plant pathogens (52). The

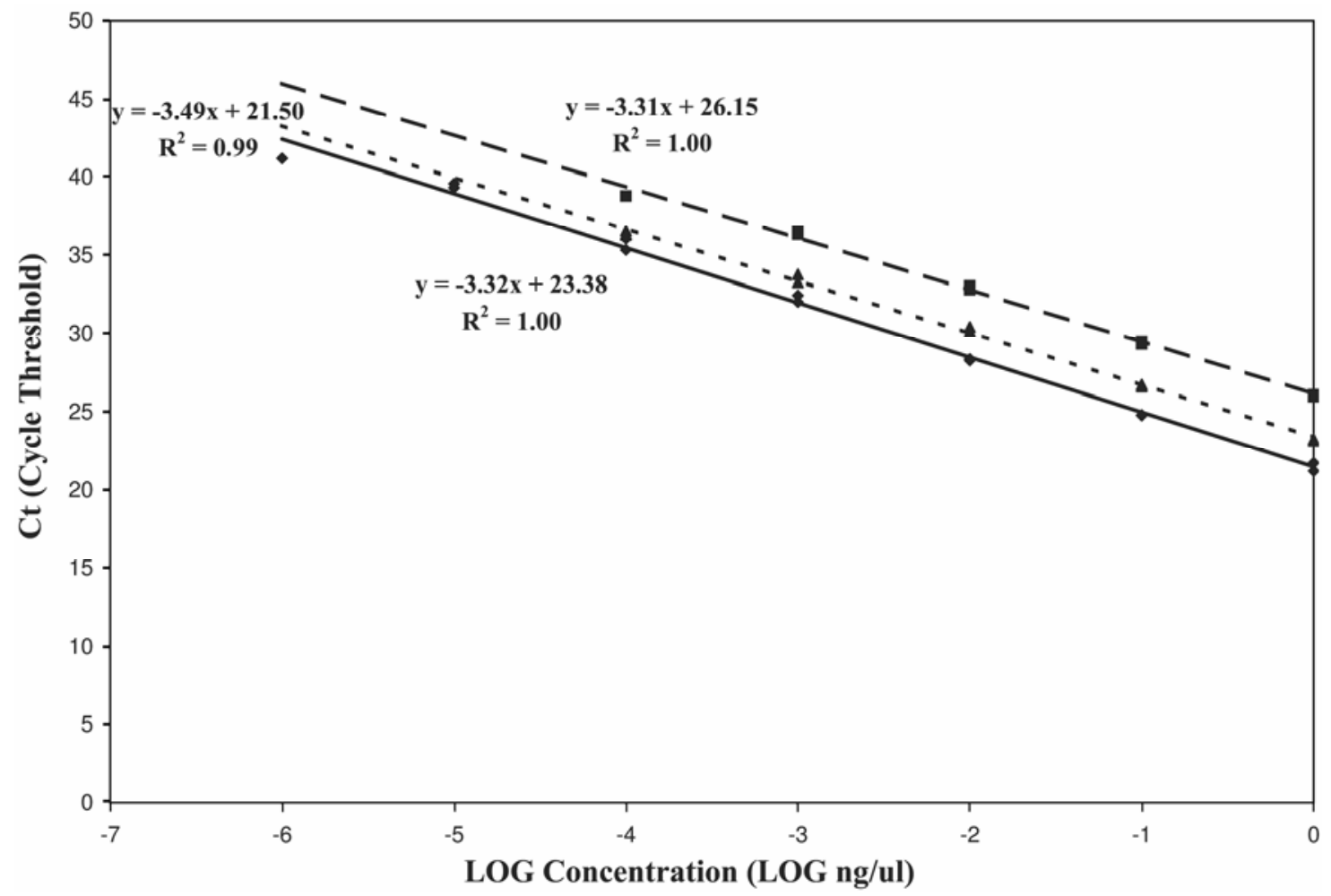

Fig. 2. Standard curves based on dilution of Phytophthora ramorum DNA for TaqMan assays targeting internal transcribed spacer (ITS), $\beta$-tubulin, and elicitin. Plots represent cycle threshold $(\mathrm{Ct})$ versus the Log of DNA concentration. P. ramorum DNA was diluted from concentrations of $1 \mathrm{ng} / \mu \mathrm{l}$ to $1 \mathrm{fg} / \mu \mathrm{l}$ in Tris buffer, $\mathrm{pH}$ 8.0, $10 \mathrm{mM}$. Assays were as follows: $\beta$-tubulin TaqMan, $\mathbf{\Delta}$ elicitin TaqMan, and ITS TaqMan. 
potential of molecular detection in plant pathology has been shown in several studies $(40,42,52)$. The advantages include speed of the assays and, the possibility of detecting nonculturable pathogens with high sensitivity. The disadvantages include cost, the need for well-equipped laboratories, and the inability to determine if the target organism is viable. Also, the risk of obtaining false positives and negatives can never be fully discounted due to the inability of fully assessing the biodiversity of target species and close relatives. To reduce the risk of incorrect identification (e.g., in regulatory applications), confirmation of morphometric properties (from culture isolation) should be included in the diagnostic protocol.

The real-time PCR assays described in this research resulted in the specific and sensitive detection of $P$. ramorum from cultures and plant samples. Tests with pure cultures of Phytophthora species and $P$. ramorum from a worldwide collection demonstrated the specificity of the ITS, $\beta$-tubulin, and elicitin TaqMan assays. No false positive or false negative results were observed with any of the assays consisting of dual probes and specific PCR primers, except for $P$. lateralis at high DNA concentration in the environmental samples experiment. However, $\mathrm{Ct}$ values were high even at those high DNA concentrations (41 for $\beta$-tubulin and 33 to 34 for elicitin) and values over 40 would be considered negative in an operational assay. In addition, the assays were tested using infected plant material from which the pathogen had been isolated, or with plant material spiked with $P$. ramorum DNA. This validation step was done as a blind test and confirmed the concordance between the various molecular assays and the increased confidence afforded by the gene region redundancy in the assays.
Our study compared molecular beacon, TaqMan, and SYBR Green assays for more than one gene region against a single target microorganism. The use of multiple gene targets increases reliability and confidence in the assays. Although it should be possible to directly multiplex the internal probe assays into single reactions, we preferred to conduct assays in separate reactions for the different gene targets. Multiplexing generally results in some competition among the PCR products and could reduce the amplification efficiency and thus the sensitivity of the assays. Molecular beacons and TaqMan probes also have built-in redundancy of polymorphisms and give two potential levels of specificity in their design: the PCR primers and the internal dual-labeled probe. In the assays we developed, this provided several polymorphic nucleotides between the target $P$. ramorum and related taxa. Even for the closely related $P$. lateralis, which has only $1.4 \%$ divergence with $P$. ramorum in the ITS region, it was possible to design a TaqMan assay with one polymorphic nucleotide per PCR primer, and an additional three polymorphic nucleotides within the TaqMan probe. The extra specificity given by the internal probes could be significant in reducing the probability of false positives. As SYBR Green intercalates nonspecifically into all double-stranded DNA molecules during the reaction, the assay must rely entirely on the PCR primers for specificity (21). In addition, the inhibition of the Taq DNA polymerase by SYBR Green could result in lower specificity (2). In our experiments, the annealing temperature was lowered in the reactions using SYBR Green compared with those using internal probes to counter this inhibition. Since the same primers were used in the SYBR Green and the TaqMan and molecular beacon as-

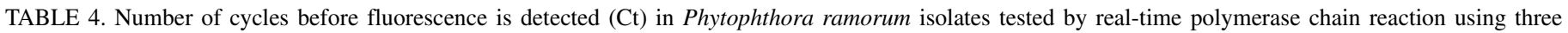
different gene regions (internal transcribed spacer [ITS], $\beta$-tubulin, and elicitin) with TaqMan

\begin{tabular}{|c|c|c|c|c|c|c|c|c|}
\hline \multirow[b]{3}{*}{ CBS number } & \multirow[b]{3}{*}{ Origin } & \multirow[b]{3}{*}{ Isolate number } & \multicolumn{6}{|c|}{$\mathrm{Ct}^{\mathrm{a}}$} \\
\hline & & & \multicolumn{2}{|c|}{ ITS } & \multicolumn{2}{|c|}{ Elicitin } & \multicolumn{2}{|c|}{$\beta$-Tubulin } \\
\hline & & & Mean $\mathrm{Ct}^{\mathrm{b}}$ & Standard error & Mean $\mathrm{Ct}^{\mathrm{b}}$ & Standard error & Mean $\mathrm{Ct}^{\mathrm{b}}$ & Standard error \\
\hline 101327 & Netherlands & PD 93/56 & 17.71 & 0.58 & 19.05 & 0.04 & 23.41 & 0.57 \\
\hline 101326 & Netherlands & PD 98/8/6933 & 19.61 & 0.69 & 20.54 & 0.04 & 24.90 & 0.72 \\
\hline 110538 & California & $\operatorname{Pr} 65$ & 19.26 & 1.61 & 19.82 & 0.24 & 23.76 & 0.62 \\
\hline 110601 & California & Pr84-sz & 26.57 & 0.89 & 26.04 & 0.31 & 30.14 & 0.79 \\
\hline 110543 & Oregon & $\operatorname{Pr} 159$ & 17.23 & 0.17 & 19.17 & 0.35 & 23.07 & 0.71 \\
\hline 110537 & California & $\operatorname{Pr} 52$ & 18.92 & 0.51 & 21.29 & 0.23 & 24.75 & 0.56 \\
\hline 110541 & California & Pr86 & 21.10 & 0.26 & 21.36 & 0.37 & 24.87 & 0.67 \\
\hline 110539 & California & $\operatorname{Pr} 70$ & 18.27 & 0.68 & 18.86 & 1.50 & 23.35 & 0.19 \\
\hline 109279 & Germany & BBA 13/99-1 & 18.80 & 0.55 & 19.29 & 0.18 & 23.98 & 0.49 \\
\hline 101554 & Germany & BBA $2 / 4$ & 19.52 & 0.94 & 19.84 & 0.20 & 24.21 & 1.19 \\
\hline 110545 & Poland & $\mathrm{Rh} / 2 / 00$ & 19.67 & 1.02 & 19.80 & 0.44 & 23.83 & 0.97 \\
\hline 110548 & France & adc 02.09 & 27.86 & 0.74 & 27.36 & 0.42 & 31.61 & 0.60 \\
\hline 101553 & Germany & BBA 9/95 Туре & 20.66 & 0.51 & 21.05 & 0.17 & 25.18 & 0.61 \\
\hline 101329 & Netherlands & PD 98/8/6285 & 16.91 & 0.57 & 18.71 & 0.24 & 22.73 & 0.48 \\
\hline 101551 & Germany & BBA 12/98 & 19.39 & 0.42 & 19.38 & 0.38 & 23.66 & 0.72 \\
\hline 101332 & Netherlands & PD 94/844 & 17.78 & 0.86 & 18.48 & 0.26 & 22.56 & 0.72 \\
\hline 101330 & Netherlands & PD 98/8/5233 & 18.65 & 0.62 & 19.63 & 0.19 & 24.17 & 0.76 \\
\hline 110546 & Poland & $\mathrm{Rh} / 6 / 00$ & 27.71 & 1.20 & 26.61 & 0.32 & 31.37 & 1.22 \\
\hline 101548 & Germany & BBA 69082 & 18.44 & 1.24 & 19.00 & 0.33 & 22.74 & 1.06 \\
\hline 101550 & Germany & BBA 14/98-a & 19.93 & 0.89 & 20.87 & 0.24 & 24.72 & 0.83 \\
\hline 110544 & California & PrPRJL3.5.3 & 18.19 & 1.17 & 20.13 & 0.29 & 23.72 & 0.87 \\
\hline 109278 & Germany & BBA 16/99 & 19.67 & 0.70 & 20.40 & 0.39 & 24.59 & 0.61 \\
\hline 101552 & Germany & BBA $9 / 3$ & 18.97 & 0.61 & 17.94 & 0.15 & 22.04 & 0.60 \\
\hline 101549 & Germany & BBA $104 / 5$ & 19.80 & 1.05 & 19.81 & 0.19 & 24.31 & 0.88 \\
\hline 101331 & Netherlands & PD 98/8/2627 & 17.55 & 0.70 & 18.44 & 0.15 & 22.90 & 0.84 \\
\hline 110535 & California & Pr03 & 19.40 & 0.51 & 19.92 & 0.06 & 23.07 & 0.67 \\
\hline 110547 & Poland & $\mathrm{Rh} / 122 / 98$ & 26.06 & 1.01 & 25.67 & 0.11 & 30.20 & 0.88 \\
\hline 110536 & California & Pr04 & 19.04 & 0.75 & 20.75 & 0.76 & 23.58 & 0.79 \\
\hline 110542 & California & $\operatorname{Pr} 110$ & 19.47 & 0.40 & 20.47 & 0.48 & 24.12 & 0.77 \\
\hline 110534 & California & Pr01 & 18.39 & 0.91 & 19.84 & 0.46 & 23.39 & 0.70 \\
\hline \multicolumn{9}{|l|}{ Average $\mathrm{Ct}$} \\
\hline by TaqMan & & & 20.02 & 2.97 & 20.65 & 2.460 & 24.70 & 2.57 \\
\hline
\end{tabular}

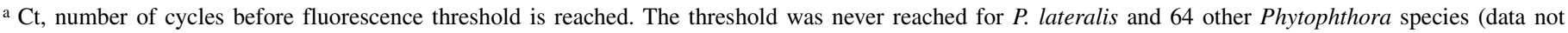
shown).

b Mean Ct was calculated with triplicates and standard error was obtained. 
says, this could have resulted in a lower specificity in SYBR Green.

The TaqMan assays developed here produced very high levels of amplification efficiency. The fluorescence continued to increase even after 40 cycles in some trials, suggesting the reaction com- ponents had not yet become limiting even if the reaction was very efficient. In a dilution series of $P$. ramorum DNA from 1 fg to 10 ng, the TaqMan system with elicitin, $\beta$-tubulin, and ITS required on average $3.30,3.30$, and 3.60 cycles per 10 -fold dilution to pass the threshold, which is very close to the theoretical value of 3.33

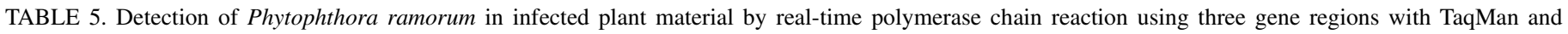
comparison with other methods

\begin{tabular}{|c|c|c|c|c|c|c|}
\hline \multirow[b]{3}{*}{ Samples } & \multirow[b]{3}{*}{$\operatorname{Host}^{\mathrm{b}}$} & \multirow[b]{3}{*}{ PARP-V8 isolation } & \multirow{3}{*}{$\begin{array}{l}\text { TaqMan } \\
\operatorname{cox} \mathrm{I} / \mathrm{II}^{\mathrm{c}}\end{array}$} & \multicolumn{3}{|c|}{$\mathrm{Ct}^{\mathrm{a}}$} \\
\hline & & & & \multicolumn{3}{|c|}{ TaqMan } \\
\hline & & & & $\beta$-Tubulin & ITS & Elicitin \\
\hline PU2 & Bay laurel* & Negative & Negative & 39.58 & None & None \\
\hline PU3 & Bay laurel* & Negative & Negative & None & None & None \\
\hline PU4 & Bay laurel* & Negative & Negative & None & None & None \\
\hline PU5 & Bay laurel* & Negative & Negative & None & None & None \\
\hline PU6 & Bay laurel* & Negative & Negative & None & None & None \\
\hline PU8 & Tan oak* & Negative & Negative & None & None & None \\
\hline PU9 & Tan oak* & Negative & Negative & None & None & None \\
\hline PU10 & Tan oak* & Negative & Negative & None & None & None \\
\hline PU11 & Tan oak* & Negative & Negative & None & None & None \\
\hline PU12 & California coffee berry* & Negative & Negative & None & None & None \\
\hline PU13 & California coffee berry* & Negative & Negative & None & None & None \\
\hline PU14 & California coffee berry* & Negative & Negative & None & None & None \\
\hline PU15 & Bay laurel* & Negative & Negative & None & None & None \\
\hline PU21 & Bay laurel* & Negative & Negative & None & None & None \\
\hline PU25 & Bay laurel* & Negative & Negative & None & None & None \\
\hline PU26 & Bay laurel* & Negative & Negative & None & None & None \\
\hline PU27 & Bay laurel* & Negative & Negative & None & None & None \\
\hline PU29 & Bay laurel* & Negative & Negative & None & None & None \\
\hline PU30 & Tan oak* & Negative & Negative & None & None & None \\
\hline PU31 & Tan oak* & Negative & Negative & None & None & None \\
\hline PU33 & Tan oak* & Negative & Negative & None & None & None \\
\hline PU36 & Tan oak* & Negative & Negative & None & None & None \\
\hline PU38 & Tan oak* & Negative & Negative & None & None & None \\
\hline PU39 & Christmas berry* & Negative & Negative & None & None & None \\
\hline PU18 & Bay laurel* & Positive & Positive & 36.04 & 32.83 & 30.39 \\
\hline PU19 & Bay laurel* & Positive & Positive & 38.47 & 36.59 & 33.69 \\
\hline PU20 & Bay laurel* & Positive & Positive & 36.57 & 33.37 & 30.29 \\
\hline PU28 & Bay laurel* & Positive & Positive & 38.37 & 33.56 & 30.66 \\
\hline PU32 & Tan oak* & Positive & Positive & 34.10 & 29.57 & 29.00 \\
\hline PU1 & Madrone* & Negative & Positive & 28.45 & 23.59 & 22.70 \\
\hline PU16 & Bay laurel* & Negative & Positive & None & 39.21 & 33.76 \\
\hline PU17 & Bay laurel* & Negative & Positive & 37.43 & 36.01 & 31.54 \\
\hline PU22 & Bay laurel* & Negative & Positive & 39.56 & 39.52 & 34.45 \\
\hline PU23 & Bay laurel* & Negative & Positive & 38.80 & 34.68 & 32.27 \\
\hline PU24 & Bay laurel* & Negative & Positive & 36.27 & 28.26 & 30.57 \\
\hline PU34 & Tan oak* & Negative & Positive & 40.61 & 38.48 & 31.81 \\
\hline PU35 & Tan oak* & Negative & Positive & 39.96 & 39.64 & 31.28 \\
\hline PU37 & Tan oak* & Negative & Positive & 40.55 & 37.50 & 32.09 \\
\hline \multicolumn{7}{|c|}{ Controls and spiked samples } \\
\hline PU40 & Live oak** & Spiked with $1.3 \mathrm{ng} / \mu \mathrm{l}^{\mathrm{d}}$ & Correct & 28.29 & 22.77 & 21.40 \\
\hline PU41 & Live oak** & Spiked with $0.65 \mathrm{ng} / \mu \mathrm{l}^{\mathrm{d}}$ & Correct & 30.33 & 24.11 & 22.48 \\
\hline PU44 & Live oak** & Spiked with 121 pg/ul ${ }^{\mathrm{d}}$ & Correct & 33.52 & 27.64 & 25.64 \\
\hline PU43 & Live oak** & Spiked with $62 \mathrm{pg} / \mu \mathrm{l}^{\mathrm{d}}$ & Correct & 32.24 & 24.56 & 25.35 \\
\hline PU42 & Live oak** & Spiked with $4.3 \mathrm{ng} / \mu \mathrm{l}^{\mathrm{e}}$ & Correct & None & None & None \\
\hline PU45 & No plant DNA** & P. ramorum CBS 101553 & Correct & 25.88 & 19.33 & 19.10 \\
\hline PU46 & Camellia** & Spiked with $3.75 \mathrm{ng} / \mu \mathrm{l}^{\mathrm{d}}$ & Correct & 33.85 & 20.25 & 19.12 \\
\hline PU47 & Camellia** & Spiked with $125 \mathrm{pg} / \mu \mathrm{l}^{\mathrm{d}}$ & Correct & 32.28 & 28.24 & 25.90 \\
\hline PU48 & Camellia** & Not spiked & Correct & None & None & None \\
\hline PU49 & Camellia** & Not spiked & Correct & None & None & None \\
\hline \multirow[t]{2}{*}{ PC1 } & Positive control, & & & & & \\
\hline & P. ramorum CBS 101553 & & & 29.05 & 25.13 & 22.27 \\
\hline \multirow{2}{*}{$\begin{array}{l}\text { Plat } \\
\text { NC }\end{array}$} & P. lateralis CBS 168.42 & & & $>41.00$ & None & $>33.00$ \\
\hline & $\begin{array}{l}\text { Negative control, } \\
\text { no template DNA }\end{array}$ & & & None & None & None \\
\hline
\end{tabular}

a Threshold was set at 0.009 in the Opticon Monitor software.

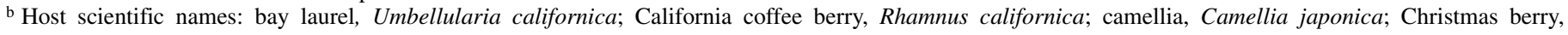
Heteromeles arbutifolia; live oak, Quercus agrifolia; madrone, Abutus menziesii; and tan oak, Lithocarpus densiflorus. *, sample origin: Monterey County, CA, Big Sur area; **, sample origin: Monterrey County, CA, USDA-ARS Salinas station.

c Bold positives samples, confirmed by sequence analysis of the spacer region between the coxI and coxII genes.

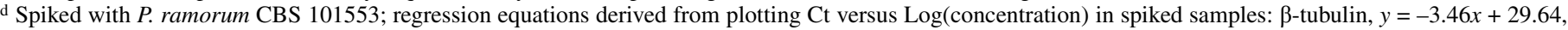
$r^{2}=0.90 ;$ ITS, $y=-3.60 x+28.82, r^{2}=0.96$; and elicitin, $y=-3.41 x+21.71, r^{2}=0.98$.

e Spiked with $P$. pseudosyringae EH P96. 
if the DNA molecules are doubled at every cycle (Fig. 2). The lower than $100 \%$ amplification efficiency could be explained by several factors, including the addition of plant DNA in our dilution series to reproduce amplification conditions encountered when processing field samples. In contrast, SYBR Green and molecular beacon fluorescence reached a plateau probably because fluorescence is generated "de novo" at every cycle by the intercalation of the SYBR Green dye in the double-stranded DNA during extension or by the hybridization of the molecular beacon at annealing. Alternatively, it is possible that the dye used for the TaqMan probe was more fluorescent than in the other assays, although FAM was used in all those assays and different quenchers were used for molecular beacon and TaqMan. However, the $\mathrm{Ct}$ values and the overall intensity of fluorescence of each sample followed the same trends among the three types of DNA detection assays (Fig. 1).

DNA extracts from 65 of the 84 documented Phytophthora species were tested in our study with the ITS, $\beta$-tubulin, and elicitin TaqMan assays. These $P$. ramorum-specific assays did not cross react with other Phytophthora species when tested at 5 to $110 \mathrm{ng}$, including the closely related $P$. hibernalis. However, at high concentrations $(8 \mathrm{ng} / \mu \mathrm{l})$, we did get some cross-reaction with $P$. lateralis using the $P$. ramorum-specific assays for the elicitin marker. Similar cross-reactivity has been reported between $P$. ramorum and $P$. lateralis for an ITS TaqMan assay (53). The three TaqMan assays also correctly detected $P$. ramorum in the plant tissue extracts tested. The sensitivity of the TaqMan assay was approximately four to seven cycles higher when used with the ITS and elicitin probes compared with the mean $\mathrm{Ct}$ of $\beta$-tubulin with the same samples (Table 5). This would make the TaqMan-ITS and TaqMan-elicitin assays approximately 1 or 2 orders of magnitude more sensitive than the $\beta$-tubulin assay with any of the techniques used.

By comparing standard curves, we could determine that the ITS TaqMan assay was the most sensitive, followed by the elicitin and $\beta$-tubulin assays. The TaqMan ITS assay yielded Ct values that were on average 4.5 cycles lower than the $\beta$-tubulin assays and 1.94 cycles lower than the elicitin assay. This is somewhat expected since rDNA consists of a tandemly repeated gene cluster, and therefore a single cell contains several copies of the cistron (61). Elicitin is also known to have multiples copies (49). By contrast, $\beta$-tubulin is usually found in fewer copies $(3,57)$. Using genes in multiple copies allows detection of smaller amounts of target DNA compared with assays based on single copy genes. Molecular diagnosis of $P$. ramorum based on nested PCR amplification of the ITS has been reported $(18,19,26)$. Although nested PCR can be very powerful and sensitive, it requires additional manipulations of the amplified DNA and can therefore result in higher risks of contamination, and therefore higher rates of false positives (47). Our assay also uses the ITS region but with a single round of PCR in a closed tube assay, reducing the possibility of false positives due to carryover contamination. However, direct comparison of the nested PCR protocol with the assays described here would be necessary to determine the relative merits of each test for specificity and sensitivity.

Other PCR-based methods have been used to characterize $P$. ramorum at the DNA level. Amplified fragment length polymorphism assays have been used for molecular characterization of $P$. ramorum isolates. These studies revealed that the European and North American strains of $P$. ramorum differ $(8,29,30,35,50,59)$ and show variation. Our sequence analysis also revealed some single nucleotide polymorphism (SNP) differences between the European and North American isolates in the $\beta$-tubulin gene. Thus far, this polymorphism correlates completely with the origin of the strains (e.g., European versus North American). We are currently developing an SNP genotyping assay that allows high throughput characterization for geographic origin (5) and is in concordance with microsatellite analysis (29).
All field samples that yielded cultures of $P$. ramorum gave positive PCR results but clearly, the PCR assays also detected $P$. ramorum consistently in some samples that $P$. ramorum could not be recovered. In all but four cases, however, sequence analysis of the spacer region between the coxI and II genes confirmed the presence of the pathogen. Sequencing of this spacer region has been proven to be a valuable tool for organism identification in Phytophthora species (38) and prior evaluations with a larger number of field samples confirmed the ability of the coxI/II marker system to identify the pathogen when it could not be cultured $(39,54)$. For these four samples, clean sequence data were not obtained, perhaps due to the presence of multiple Phytophthora species in the sample. The high $\mathrm{Ct}$ values obtained when using the markers developed in this submission indicated that the amount of $P$. ramorum was probably very low. The greater sensitivity of molecular assays compared with culture assays is not entirely unexpected as culture methods can be affected by the presence of contaminants, competitors, or inhibitors (e.g., fungicides) in the tissues $(23,24)$, as well as seasonal variation (27). Moreover, nonviable pathogen propagules would result in positive PCR assays, but cultures would not be obtained.

The real-time PCR assays developed here can be a useful tool to detect $P$. ramorum rapidly and sensitively from pure cultures and plant tissue samples. Our approach allows for redundancy both in the gene regions targeted by designing assays that take advantage of SNPs at priming sites as well as at internal sites for probes. This approach, combined with use of assays for multiple gene/spacers targets, should greatly increase the confidence level of these assays and reduce the potential for false positive results in molecular testing.

\section{ACKNOWLEDGMENTS}

We thank A. de Cock and R. Nijman for cultivation of the fungi and isolation of most of the DNA samples as well as N. Desaulniers and T. Barasubiye for their help with DNA sequencing. Funding for this work was received from the Canadian Biotechnology Strategic Fund and the CBRN Research and Technology Initiative (CRTI grant 04-0045RD).

\section{LITERATURE CITED}

1. APHIS. 2004. Invasive Species and Pest Management Programs (ISPM), USDA APHIS PPQ Approved Laboratory Diagnostic Protocols, PCR Protocol. Published online. http://www.aphis.usda.gov/ppq/ispm/ pramorum/pdf_files/pcrprotocol4.pdf

2. Arezi, B., Xing, W., Sorge, J. A., and Hogrefe, H. H. 2003. Amplification efficiency of thermostable DNA polymerases. Anal. Biochem. 321:226235.

3. Ayliffe, M. A., Dodds, P. N., and Lawrence, G. J. 2001. Characterisation of a [beta]-tubulin gene from Melampsora lini and comparison of fungal [beta]-tubulin genes. Mycol. Res. 105:818-826.

4. Bakkeren, G., Kronstad, J. W., and Lévesque, C. A. 2000. Comparison of AFLP fingerprints and ITS sequences as phylogenetic markers in Ustilaginomycetes. Mycologia 92:510-521.

5. Bilodeau, G., Lévesque, C. A., de Cock, A. W. A. M., Kristjansson, G., McDonald, J., and Hamelin, R. C. 2003. Detection and identification of Phytophthora ramorum, the causal agent of sudden oak death by real-time PCR. (Abstr.) Phytopathology 93(suppl.):S8.

6. Bonnet, G., Tyagi, S., Libchaber, A., and Kramer, F. R. 1999. Thermodynamic basis of the enhanced specificity of structured DNA probes. Proc. Natl. Acad. Sci. USA 96:6171-6176.

7. Braasch, D. A., and Corey, D. R. 2001. Locked nucleic acid (LNA): Finetuning the recognition of DNA and RNA. Chem. Biol. 8:1-7.

8. Brasier, C. 2003. Sudden oak death: Phytophthora ramorum exhibits transatlantic differences. Mycol. Res. 107:258-259.

9. Brasier, C., and Kirk, S. 2004. Production of gametangia by Phytophthora ramorum in vitro. Mycol. Res. 108:823-827.

10. Brasier, C. M., Denman, S., Rose, J., Kirk, S. A., Hughes, K. J. D., Griffin, R. L., Lane, C. R., Inman, A. J., and Webber, J. F. 2004. First report of ramorum bleeding canker on Quercus falcata, caused by Phytophthora ramorum. Plant Pathol. 53:804.

11. Cooke, D. E. L., Drenth, A., Duncan, J. M., Wagels, G., and Brasier, C. M. 2000. A molecular phylogeny of Phytophthora and related oomycetes. 
Fungal Genet. Biol. 30:17-32.

12. Davidson, J. M., Garbelotto, M., Koike, S. T., and Rizzo, D. M. 2002. First report of Phytophthora ramorum on Douglas-fir in California. Plant Dis. 86:1274.

13. Davidson, J. M., Rizzo, D. M., Garbelotto, M., Tjosvold, S., and Slaughter, G. W. 2002. Phytophthora ramorum and sudden oak death in California: II. Transmission and survival. USDA For. Serv. Gen. Tech. Rep. PSW-GTR-184:741-749.

14. Davidson, J. M., Werres, S., Garbelotto, M., Hansen, E. M., and Rizzo, D. M. 2003. Sudden oak death and associated diseases caused by Phytophthora ramorum. Plant Health Progress (Online) doi:10.1094/PHP-20030703-01-DG.

15. De Cock, A. W. A. M., Neuvel, A., Bahnweg, G., de Cock, J. C. J. M., and Prell, H. H. 1992. A comparison of morphology, pathogenicity and restriction fragment patterns of mitochondrial DNA among isolates of Phytophthora porri Foister. Neth. J. Plant Pathol. 98:277-289.

16. De Merlier, D., Chandelier, A., and Cavelier, M. 2003. First report of Phytophthora ramorum on Viburnum bodnantense in Belgium. Plant Dis. 87:203.

17. Denman, S., Kirk, S. A., and Brasier, C. M. 2005. Phytophthora ramorum on Quercus ilex in the United Kingdom. Plant Dis. 89:1241.

18. Garbelotto, M. 2003. Molecular diagnostics of Phytophthora ramorum, causal agent of sudden oak death. Sudden Oak Death Online Symposium. Published online by The American Phytopathological Society doi:10.1094/SOD-2003-MG

19. Garbelotto, M., Davidson, J. M., Ivors, K., Maloney, P. E., Huberli, D., Koike, S. T., and Rizzo, D. M. 2003. Non-oak native plants are main hosts for sudden oak death pathogen in California. Calif. Agric. 57:18-23.

20. Garbelotto, M., Svihra, P., and Rizzo, D. M. 2001. Sudden oak death syndrome fells three oak species. Calif. Agric. 55:1-19.

21. Giglio, S., Monis, P. T., and Saint, C. P. 2003. Demonstration of preferential binding of SYBR Green I to specific DNA fragments in real-time multiplex PCR. Nucleic Acids Res. 31:e136.

22. Goheen, E. M., Hansen, E. M., Kanaskie, A., McWilliams, M. J., Osterbauer, N., and Sutton, W. 2002. Sudden oak death caused by Phytophthora ramorum in Oregon. Plant Dis. 86:441.

23. Hamelin, R. C., Bérubé, P., Gignac, M., and Bourassa, M. 1996. Identification of root rot fungi in nursery seedlings by nested multiplex PCR. Appl. Environ. Microbiol. 62:4026-4031.

24. Hamelin, R. C., Bourassa, M., Rail, J., Dusabenyagasani, M., Jacobi, V., and Laflamme, G. 2000. PCR detection of Gremmeniella abietina, the causal agent of scleroderris canker of pine. Mycol. Res. 104:527-532.

25. Hansen, E. M., Reeser, P. W., Sutton, W., and Winton, L. M. 2003. First report of A1 mating type of Phytophthora ramorum in North America. Plant Dis. 87:1267-1267.

26. Hayden, K., Ivors, K., Wilkinson, C., and Garbelotto, M. 2006. TaqMan chemistry for Phytophthora ramorum detection and quantification, with a comparison of diagnostic methods. Phytopathology 96:846-854.

27. Hayden, K. J., Rizzo, D., Tse, J., and Garbelotto, M. 2004. Detection and quantification of Phytophthora ramorum from California forests using a real-time polymerase chain reaction assay. Phytopathology 94:1075-1083.

28. Heid, C. A., Stevens, J., Livak, K. J., and Williams, P. M. 1996. Real time quantitative PCR. Genome Res. 6:986-994.

29. Ivors, K., Garbelotto, M., Vries, I. D. E., Ruyter-Spira, C., Hekkert, B. T., Rosenzweig, N., and Bonants, P. 2006. Microsatellite markers identify three lineages of Phytophthora ramorum in US nurseries, yet single lineages in US forest and European nursery populations. Mol. Ecol. 15(6): 1493 .

30. Ivors, K. L., Hayden, K. J., Bonants, P. J. M., Rizzo, D. M., and Garbelotto, M. 2004. AFLP and phylogenetic analyses of North American and European populations of Phytophthora ramorum. Mycol. Res. 108:378-392.

31. Jeffers, S. N., and Martin, S. B. 1986. Comparison of two media selective for Phytophthora and Pythium species. Plant Dis. 70:1038-1043.

32. Jullien, J., and Casset, C. 2003. Phytophthora ramorum. Legitimate concern in France for several ornamental nursery species. Phytoma 561:16-20.

33. Kanaskie, A., Osterbauer, N., Goheen, E., Hansen, E., McWilliams, M., and Sutton, W. 2002. Monitoring Phytophthora ramorum within and around disease patches targeted for eradication in Oregon. Presented at the Sudden Oak Death Science Symposium: The State of Our Knowledge. U.S. Dep. Agric. For. Serv., Berkeley, CA.

34. Kroon, L. P. N. M., Bakker, F. T., van den Bosch, G. B. M., Bonants, P. J. M., and Flier, W. G. 2004. Phylogenetic analysis of Phytophthora species based on mitochondrial and nuclear DNA sequences. Fungal Genet. Biol. 41:766-782.

35. Kroon, L. P. N. M., Verstappen, E. C. P., Kox, L. F. F., Flier, W. G., and Bonants, P. J. M. 2004. A rapid diagnostic test to distinguish between American and European populations of Phytophthora ramorum. Phytopathology 94:613-620
36. Lane, C. R., Beales, P. A., Hughes, K. J. D., Griffin, R. L., Munro, D., Brasier, C. M., and Webber, J. F. 2003. First outbreak of Phytophthora ramorum in England, on Viburnum tinus. Plant Pathol. 52:414.

37. Maloney, P. E., Rizzo, D. M., Koike, S. T., Harnik, T. Y., and Garbelotto, M. 2002. First report of Phytophthora ramorum on coast redwood in California. Plant Dis. 86:1274.

38. Martin, F. N., and Tooley, P. W. 2004. Identification of Phytophthora isolates to species level using restriction fragment length polymorphism analysis of a polymerase chain reaction-amplified region of mitochondrial DNA. Phytopathology 94:983-991.

39. Martin, F. N., Tooley, P. W., and Blomquist, C. 2004. Molecular detection of Phytophthora ramorum, the causal agent of sudden oak death in California, and two additional species commonly recovered from diseased plant material. Phytopathology 94:621-631.

40. Martin, R. R., James, D., and Lévesque, C. A. 2000. Impacts of molecular diagnostic technologies on plant disease management. Annu. Rev. Phytopathol. 38:207-239.

41. Mazzola, M., Andrews, P. K., Reganold, J. P., and Lévesque, C. A. 2002. Frequency, virulence, and metalaxyl sensitivity of Pythium spp. isolated from apple roots under conventional and organic production systems. Plant Dis. 86:669-675.

42. McCartney, H. A., Foster, S. J., Fraaije, B. A., and Ward, E. 2003. Molecular diagnostics for fungal plant pathogens. Pest Manag. Sci. 59:129-142.

43. Möller, E. M., Bahnweg, G., Sandermann, H., and Geiger, H. H. 1992. A simple and efficient protocol for isolation of high molecular weight DNA from filamentous fungi, fruit bodies, and infected plant tissues. Nucleic Acids Res. 20:6115-6116.

44. Moralejo, E., and Werres, S. 2002. First report of Phytophthora ramorum on Rhododendron sp. in Spain. Plant Dis. 86:1052.

45. Murphy, S. K., and Rizzo, D. M. 2003. First report of Phytophthora ramorum on canyon live oak in California. Plant Dis. 87:315.

46. Orlikowski, L. B., and Szkuta, G. 2002. First record of Phytophthora ramorum in Poland. Phytopathol. Polonica. 25:69-79.

47. Osterbauer, N., and Trippe, A. 2005. Comparing diagnostic protocols for Phytophthora ramorum in rhododendron leaves. Plant Health Progress (Online) doi:10.1094/PHP-2005-0314-01-HN

48. Osterbauer, N. K., Griesbach, J. A., and Hedberg, J. 2004. Surveying for and eradicating Phytophthora ramorum in agricultural commodities. Plant Health Progress (Online) doi:10.1094/PHP-2004-0309-02-RS.

49. Ponchet, M., Panabières, F., Milat, M.-L., Mikes, V., Montillet, J.-L., Suty, L., Triantaphylides, C., Tirillye, Y., and Blein, J. P. 1999. Are elicitins cryptograms in plant-oomycete communications? Cell. Mol. Life Sci. 56:1020-1047

50. Prospero, S., Black, J. A., and Winton, L. M. 2004. Isolation and characterization of microsatellite markers in Phytophthora ramorum, the causal agent of sudden oak death. Mol. Ecol. Notes 4:672-674

51. Rizzo, D. M., Garbelotto, M., Davidson, J. M., Slaughter, G. W., and Koike, S. T. 2002. Phytophthora ramorum as the cause of extensive mortality of Quercus spp., and Lithocarpus densiflorus in California. Plant Dis. 86:205-214

52. Schaad, N. W., and Frederick, R. D. 2002. Real-time PCR and its application for rapid plant disease diagnostics. Can. J. Plant Pathol. 24:250258.

53. Tomlinson, J. A., Boonham, N., Hughes, K. J. D., Griffin, R. L., and Barker, I. 2005. On-site DNA extraction and real-time PCR for detection of Phytophthora ramorum in the field. Appl. Environ. Microbiol. 71:6702-6710

54. Tooley, P. W., Martin, F. N., Carras, M. M., and Frederick, R. D. 2006. Real-time fluorescent PCR detection of Phytophthora ramorum and Phytophthora pseudosyringae using mitochondrial gene regions. Phytopathology 96:336-345.

55. Tyagi, S., and Kramer, F. R. 1996. Molecular beacons: Probes that fluoresce upon hybridization. Nat. Biotechnol. 14:303-308.

56. Tyagi, S., Marras, S. A. E., Vet, J. A. M., and Kramer, F. R. 2000. Molecular beacons: Hybridization probes for detection of nucleic acids in homogeneous solutions. Pages 606-616 in: Nonradioactive Analysis of Biomolecules, 2nd ed. C. Kessler, ed. Springer-Verlag, Berlin.

57. Weerakoon, N. D., Roberts, J. K., Lehnen, L. P., Wilkinson, J. M. Marshall, J. S., and Hardham, A. R. 1998. Isolation and characterization of the single Beta-tubulin gene in Phytophthora cinnamomi. Mycologia 90:85-95.

58. Werres, S. 2002. A new species of Phytophthora causes Rhododendron dieback. Rhododendron Immergruene Laubgehoelze Jahrb. 147:8.

59. Werres, S., and De Merlier, D. 2003. First detection of Phytophthora ramorum mating type A2 in Europe. Plant Dis. 87:1266.

60. Werres, S., Marwitz, R., Man in't Veld, W. A., De Cock, A. W. A. M., Bonants, P. J. M., De Weerdt, M., Themann, K., Ilieva, E., and Baayen, R. P. 2001. Phytophthora ramorum sp. nov., a new pathogen on Rhododendron and Viburnum. Mycol. Res. 105:1155-1165. 
61. White, T. J., Bruns, T., Lee, S., and Taylor, J. W. 1990. Amplification and direct sequencing of fungal ribosomal RNA genes for phylogenetics. Pages 315-322 in: PCR Protocols: A Guide to Methods and Applications.

M. A. Innis, D. H. Gelfand, J. J. Sninsky, and T. J. White, eds. Academic
Press, New York.

62. Winton, L. M., and Hansen, E. M. 2001. Molecular diagnosis of Phytophthora lateralis in trees, water, and foliage baits using multiplex polymerase chain reaction. For. Pathol. 31:275-283. 